\title{
Darja Koter
}

Akademija za glasbo, Univerza v Ljubljani

Academy of Music, University of Ljubljana

\section{Slogovni pluralizem v delih Karola Pahorja Stylistic Pluralism in the Works of Karol Pahor}

Prejeto: 4. september 2018

Sprejeto: 26. september 2018

Ključne besede: Karol Pahor, tradicionalna glasba, avantgardna glasba, slogovni pluralizem, Slavko Osterc

\section{IZVLEČEK}

Karol Pahor (1896-1974) se je kot skladatelj proslavil na več ravneh in je prepoznan je kot eden najznačilnejših učencev Slavka Osterca, njegov opus pa kaže na slogovno raznolikost, ki je posledica različnih dejavnikov. Kot skladatelj namreč odstopa od običajnih stereotipov, za katere velja, da se komponist v mladih letih opira na svoje učitelje, se nato izostri in profilira v lastno smer, ki ga vodi naprej in ob novih aktualnih kompozicijskih šolah pogosto spreminja. Skušali bomo ugotoviti, kakšne vzore in nazore je imel skozi različna obdobja in kako ga je kot skladatelja oblikovalo okolje, v katerem je živel in deloval.
Received: $4^{\text {th }}$ September 2018

Accepted: $26^{\text {th }}$ September 2018

Keywords: Karol Pahor, traditional music, avantgarde music, stylistic pluralism, Slavko Osterc

\section{ABSTRACT}

Composer Karol Pahor (1896-1974) stood out on several levels and is recognized as one of the most distinguished students of Slavko Osterc, his opus shows the stylistic diversity resulting from various factors. As a composer he deviates from the usual stereotypes, the standard being that the composer relies on his teacher during his formative years then sharpens and profiles in his own direction which leads him forward and often changes with the new contemporary compositional schools. This article attempts to determine what patterns and views he had through different periods and how he was shaped as a composer by the environment in which he lived and worked.

\section{Za uvod}

Tržačan Karol Pahor (1896-1974) sodi med tiste slovenske skladatelje, ki so se formalno izšolali za instrumentaliste, učitelje in zborovodje ter si prizadevali, da bi svoje 
glasbeno delovanje nadgradili in usmerili h komponiranju. Pahor je temeljno glasbeno-teoretično znanje pridobil na goriškem učiteljišču, kar mu je omogočalo harmonizacije ljudskih napevov in pisanje preprostejših vokalnih skladb, vendar ga to dolgoročno ni zadovoljilo. Da bi postal skladatelj, je po prvi svetovni vojni odšel na dunajsko akademijo, vendar je moral študij po nekaj mesecih opustiti. Poslej se je predal violinski igri, pedagoškemu poklicu in vodenju zborov. V 20. letih je napisal nekaj priredb bosanskih ljudskih pesmi in drugih vokalnih skladb, objavljenih v Zborih in Mali novi muziki. Želja po boljši glasbeno-teoretični izobrazbi in komponiranju je bila v njem vseskozi prisotna, zato je iskal možnost njene uresničitve. Obrnil se je na Slavka Osterca, s katerim sta nato izpeljala večletno dopisno izobraževanje. Le-to mu je vlilo samozaupanje, da se je pri svojih štiridesetih proglasil za skladatelja. ${ }^{1}$ Njegova pot je bila izrazito večplastna in je s tega stališča še posebno zanimiva za proučevanje. Kot skladatelj namreč odstopa od običajnih stereotipov, za katere velja, da se komponist v mladih letih opira na svoje učitelje, se nato izostri in profilira v lastno smer, ki ga vodi naprej in ob novih aktualnih kompozicijskih šolah pogosto spreminja. Skušali bomo ugotoviti, kaj ga je spodbujalo h komponiranju, kakšne vzore je imel in kako ga je kot skladatelja oblikovalo okolje, v katerem je živel in deloval. Pahor se je v dijaških letih naučil klasičnih harmonizacij, nato ob Ostercu ekspresionističnih, neoklasicističnih in atonalnih prvin, narodnoosvobodilna vojna pa ga je prelevila v partizanskega skladatelja, kar je vsaj deloma ostal tudi v socialistični povojni dobi. Tisto, kar se zdi v njegovi skladateljski karieri najbolj presenetljivo, je to, da se ni nikoli vrnil k slogu, ki ga je razvil pod Osterčevim vplivom, pa čeprav je pred vojno zagotavljal, da je to edina prava pot, ko pravi: "če hoče človek povedati drugim to, kar nosi v sebi, odnosno če hoče prekričati krik današnjega človeka /.../, se mu res zdi smešno še vsako diatonsko moraliziranje smě̌en se mu zdi pravzaprav celoten kromatičen aparat, ki je tako zelo, zelo omejen. ${ }^{2}$

Nasprotno pa je v svojih zrelih, povojnih letih zapisal:

Tudi po prvi svetovi vojni je svet zajela ista mrzlica kakor po drugi, da smo se mladi ljudje začeli ubadati z najrazličnejšimi -izmi, s celo vrsto tonskih sistemov itd., ki so bili takrat na pohodu. Sam sem v to smer žrtvoval mnogo dragocenega časa, vendar mi še danes ni žal, kajti le tako sem se lahko uveril, da za umetnost tu ni poti naprej in da mora stopiti previdno naprej le po že utrjenih poteh. ${ }^{3}$

\section{Od tradicije do avantgarde}

Karol Pahor se je v svojih otroških letih najprej seznanil z istrsko ljudsko melodiko, nad katero se je navdušil do te mere, da jo je desetletja kasneje vpel v številna dela svojega skladateljskega opusa. Ob ljudskih vižah je občudoval mestne godbenike in si želel igrati na gosli, kar mu je bilo dano v osnovni šoli, pri dvanajstih letih pa so ga starši

1 O Pahorjevem življenju in delu glej razprave v publikaciji Pahorjev zbornik, ur. Edo Škulj (Ljubljana: Akademija za glasbo, 2005).

2 Odlomek pisma Slavku Ostercu z dne 16. 11. 1934, glej v: Dragotin Cvetko, Fragment glasbene moderne: izpisem Slavku Ostercu (Ljubljana: Slovenska akademija znanosti in umetnosti, 1988), 257.

3 Glej Luisa Antoni, »Pahorjeva tržaška leta«, Pahorjev zbornik, 23-24. 
vpisali v violinsko šolo (Liceo Musicale) tržaškega violinskega pedagoga Arthurja Vrama. Le-ta je bil diplomant dunajske šole, vendar je poučeval po takrat izjemno aktualni Ševčíkovi metodi (poimenovani po Otokarju Ševčíku), ki jo je kot prvi prinesel v tržaško okolje. ${ }^{4}$ Vram je bil priznan pedagog, pri katerem se je Pahor profiliral kot violinist in se navzel Ševčíkove metode, po kateri je sam kasneje tudi poučeval. ${ }^{5}$ Učenje violine in splošno zanimanje za glasbo ga je po dveh razredih realke pripeljalo na goriško učiteljišče, ki je bilo na začetku 20. stoletja pomembno za šolanje številnih umetniško nadarjenih Primorcev. ${ }^{6} \mathrm{~V}$ Pahorjevem času je glasbene predmete poučeval pedagog češkega porekla Josip Michl, sicer vodja šole in zbora Pevskega in glasbenega društva v Gorici. Kot diplomant praškega konservatorija je na Goriškem deloval kot violinski pedagog, zborovodja in skladatelj ter bil osrednja glasbena osebnost svojega časa. ${ }^{7} \mathrm{Mi}$ chl je na učiteljišču poučeval violino in glasbeno teorijo, zato menimo, da je Pahor ob njem igranje violine nadgradil in dobil prva bolj poglobljena glasbeno-teoretična znanja. Ni izključeno, da je bil Michl tudi njegov zasebni učitelj violine. ${ }^{8}$ Vojne razmere so Pahorjevo generacijo vključno z njim pahnile na fronto, kjer so preživeli le redki. Po vrnitvi v Trst se je udejstvoval kot komorni glasbenik in pomožni učitelj, ob tem pa še naprej študiral violino. Če sledimo najstarejšemu pisnemu viru z njegovimi biografskimi podatki in osebnemu pričevanju, se je po vojni ponovno vpisal na Vramov licej, medtem ko naj bi glasbeno teorijo študiral pri priznanem tržaškem skladatelju Antoniu Illersbergu. ${ }^{9}$ Ker ni podatkov, da bi bil redno vpisan na tržaški konservatorij, se predvideva, da je bil študij zasebne narave. Kot kaže datacija mešanega zbora Hrepenenje (bes. Oton Župančič), je v letu 1922 na dunajski Akademiji za glasbo in upodabljajočo umetnost (Akademie für Musik und darstellende Kunst) študiral kompozicijo. ${ }^{10}$ Kaj več o tem Pahorjevem obdobju ni znanega, zdi se, da je to zanj temno plat življenja kasneje zavestno potisnil v ozadje, saj je bil zaradi skromnih gmotnih razmer primoran študij po nekaj mesecih opustiti. Kot piše Fran Žgur, naj bi na Dunaju opravil izpit iz harmonije, kontrapunkt pa študiral pri znanem pedagogu Josefu Marxu, pri katerem sta se urila tudi Lucijan Marija Škerjanc in Marjan Kozina. ${ }^{11}$ Sam Pahor dunajsko obdobje omenja le na kratko, ko sta z Ostercem razpravljala o najprimernejši literaturi za študij harmonije in kontrapunkta. Osterc je na začetku njune dopisne šole ugotavljal, da vaje iz klasične harmonije niso potrebne, saj naj bi jo obvladal "prav dobro« in mu svetoval, da se izpopolnjuje s pomočjo Riemannove Harmonielehre, čeprav Osterc nad tem priročnikom ni bil najbolj navdušen. ${ }^{12}$ Pahor se je po neuspelem poskusu študija

4 Prav tam, 21.

5 Maruša Zupančič, „V iskanju lastne identitete: češki violinisti kot glavni tvorci violinizma na Slovenskem《, De musica disserenda, IV/2 (2008): 113-14.

6 Antoni, »Pahorjeva tržaška leta«, 17-18.

7 Marko Waltritsch, Šola Glasbene matice v Gorici: ob 25. letnici (Gorica: Šola Glasbene matice v Gorici, 1987), 7-13.

8 Antoni, "Pahorjeva tržaška leta«, 22-23.

9 Prim. prvo objavljeno Pahorjevo biografijo v Zborih. Fran Žgur, «Karol Pahor«, Zbori III, št. 3-4 (1927): 14 in Pahorjevo rokopisno biografijo z dne 22. 12. 1946, kjer pravi, da je po razpadu Avstro-Ogrske nadaljeval študij v Trstu, na Dunaju in v Bologni.

10 Natančne letnice iz dosegljivih virov ni mogoče določiti, saj se eksplicitno ne navaja. Rokopis skladbe Hrepenenje lahko dokazuje, da je študiral leta 1922 (Glej NUK, Glasbena zbirka, mapa Karol Pahor), sam pa je o tem obdobju zapisal, da je v Bologni diplomiral leta 1923 ter istočasno študiral še kompozicijo, glej Rotar Pance, »Pedagoško delo K. Pahorja na Akademiji za glasbo«, 59 .

11 Žgur, prav tam.

12 Prim. Andrej Rijavec, »Pahorjevo predkompozicijsko dopisno šolanje pri Slavku Ostercu«, Muzikološki zbornik XXV (1989): 124. 
kompozicije vneto oprijel violine in junija 1923 na Glasbenem liceju v Bologni (Liceo Musicale di Bologna) kot eksternist tudi diplomiral. ${ }^{13}$

V prvih letih po prvi svetovni vojni je napisal le malo skladb, poleg že omenjene, so nastali ženski in/ali mladinski zbori Pojdimo spat, Na semnju (obe bes. Karol Širok), Pomlad gre v svet (bes. Stanko Kosovel) idr., napisani v diatoničnem slogu. Izjema je mešani zbor Hrepenenje, najverjetneje iz časa študija na Dunaju pod mentorstvom profesorja Marxsa. v Tako v izrazu kot harmoniji kaže takrat aktualne poznoromantične poteze, kot so melodične linije s harmonsko tujimi toni, mediantne zveze, mutacije, modulacije v oddaljene tonalitete, stranske dominante idr., kar je pripomoglo k rahljanju tonalnosti. ${ }^{14}$ To je Pahorjevo edino delo, ki ga lahko pripišemo njegovemu dunajskemu obdobju in vplivu tamkajšnjih učiteljev. Že v naslednji po dataciji znani skladbi, mešanem zboru Vipavska (bes. Fran Žgur) iz leta 1925, je Pahor v kompozicijski tehniki stopil korak nazaj proti tradiciji, kar bi lahko pomenilo, da v drznejših harmonijah ni bil dovolj vešč in zato ne primerno samozavesten, da bi hodil po začeti poti. Potrebno je upoštevati, da je Hrepenenje nastalo kot študijsko delo, pri katerem ga je vodila vešča profesorjeva roka. Ob tem predvidevamo, da si je Pahor želel izvedb in javnega priznanja, kar naj bi po njegovem prepričanju prišlo z deli, ki so imela več možnosti za izvedbo, torej s takšnimi s klasično zgradbo. ${ }^{15}$ Pahorjeva dela so bila pri urednikih različnih zbirk in revij prepoznana kot tehtna, kajti le tako lahko razumemo, da so bila v večini kmalu po nastanku tudi natisnjena v priznanih publikacijah, kot je bila zbirka Otroške pesmi v uredništvu Srečka Kumarja (Trst, 1924), revija Zbori pod urednikovanjem Zorka Prelovca in Mala nova muzika Emila Adamiča. S komponiranjem instrumentalnih del se v tem obdobju ni poskusil.

Pahorjevo novo obdobje se je začelo leta 1924, ko se je iz Idrije, kjer je kakšno leto uspešno vodil glasbeno šolo in več ansamblov, zaradi fašističnih pritiskov umaknil v Jugoslavijo in se za krajši čas zaposlil v orkestru ljubljanske Opere. ${ }^{16}$ To ga ni zadovoljilo, pa čeprav mu je bilo mesto violinista zagotovljeno dolgoročno. Ljubljanska Opera se je v prvih povojnih letih ubadala $z$ velikim pomanjkanjem ustreznega kadra, kar je pomenilo, da je bil Pahor v orkestru dobrodošel, vendar zaradi neurejenih razmer ni ostal. Na priporočilo kolega Emila Adamiča je še isto leto sprejel mesto učitelja glasbe na gimnaziji v Banjaluki, ${ }^{17}$ kjer se je vključil tudi v tamkajšnje glasbeno društvo Nada in ga dlje časa vodil. ${ }^{18}$ Adamič je dobro poznal ljudsko dediščino jugoslovanskih narodov in tako tudi bogastvo z območja Bosne. Priredil je več tamkajšnjih pesmi (npr. zbori Iz bosanskega perivoja) in zanje navdušil tudi Pahorja. Tako se zdi, da so prav ambicije po skladanju odločilno vplivale na Pahorjevo življenjsko pot, čeprav je imel ponudbe, da bi odšel za koncertnega mojstra v Zagreb ali za učitelja in ravnatelja glasbene šole na Ptuj. O tem, ali je bil Emil Adamič kot skladatelj njegov vzornik, ni pisnih virov ali

13 O tem najbolj verodostojno piše Luigi Verdi v prispevku »Karol Pahor a Bologna«, Pahorjev zbornik, $27-31$.

14 Prim. Marko Vatovec, »Pahorjev opus mešanih zborov in njegov Očenaš hlapca Jerneja", Pahorjev zbornik, 89-91.

15 Skladbo Vipavska je leta 1927 natisnil Zorko Prelovec v Zborih, leta 1930 pa prvi izvedel zbor Glasbene matice Maribor pod vodstvom Vasilija Mirka. Prim. Vatovec, »Pahorjev opus mešanih zborov in njegov Očenaš hlapca Jerneja«, 91.

16 Pahor je svojo odločitev pojasnil v izjavi, ki se hrani v personalni mapi v Arhivu Akademija za glasbo Univerze v Ljubljani. Prim. Rotar Pance, "Pedagoško delo K. Pahorja«, 57.

17 Prav tam.

18 Primož Kuret, „Življenje in delo K. Pahorja«, Pahorjev zbornik, 8. 
pričevanj, vendar je to precej mogoče, saj je veljal za najpomembnejšega skladatelja zborovske glasbe in mentorja številnim posameznikom. S Pahorjem sta se gotovo dobro poznala še iz Trsta, kjer sta bila oba odkrita podpornika leta 1923 ustanovljenega legendarnega učiteljskega pevskega zbora pod vodstvom Srečka Kumarja. Pahor se je zaradi pisne podpore zameril fašističnim oblastem do te mere, da so ga preganjali in končno pregnali v Idrijo, nato pa v Jugoslavijo. Kot pravi sam, je odšel v Bosno predvsem zaradi "nabiranja narodnih motivov za obdelavo" in kot se je izkazalo, so ga izjemno pritegnili, saj je številne tudi uglasbil. ${ }^{19} \mathrm{~V}$ dveh letih vsestranskega delovanja $\mathrm{V}$ Banjaluki, se je prvenstveno ukvarjal s poučevanjem, vodenjem zborov in ne nazadnje z organiziranjem prireditev, ob tem pa spoznaval in zapisoval narodno blago, ki mu je služilo za komponiranje. Leta 1926 je uglasbil Bosansko kolo (mešani zbor), ki je tudi natisnjeno, ${ }^{20}$ nekatere bosanske sevdalinke za moške in mešane zasedbe pa so ostale v rokopisu (NUK, Glasbena zbirka, fond Karol Pahor in zapuščina Vasilija Mirka). V Banjaluki pa očitno ni bil popolnoma zadovoljen, sicer ne bi razmišljal o vrnitvi v slovensko okolje. Tudi tokrat se je odločil skladno s predlogom Emila Adamiča, ki ga je priporočil na glasbeni šoli ptujske Glasbene matice. S šolskim letom 1926/27 je Pahor postal tam ravnatelj, učitelj violine in glasbene teorije, zborovodja mladinskega in odraslega zbora ter vodja orkestra. Ob vsem si je prizadeval za prenovitev učnih programov, boljše delovne pogoje učiteljev, vodil koncertno dejavnost gostujočih in domačih glasbenikov in ne nazadnje deloval kot komorni glasbenik v klavirskem triu. ${ }^{21}$ Številne dejavnosti so mu preprečile, da bi napredoval kot skladatelj, saj je v štiriletnem ptujskem obdobju zmogel napisati zgolj eno delo, to je Snežec (glas in klavir, 1926), ${ }^{22}$ napisan v diatoničnem glasbenem stavku s preprosto klavirsko spremljavo, pri čemer ne gre spregledati, da ima skladbica izvirno melodiko. ${ }^{23}$ Nezmožnost komponiranja je Pahorja očitno pestila, zato je po nekaj letih ponovno razmišljal o selitvi, in sicer v Maribor. ${ }^{24} \mathrm{~V}$ ptujskem obdobju je tako v šolstvu kot $\mathrm{z}$ ansambli, ki jih je vodil, dosegel odlične uspehe, prav tako se je dokazal kot dober organizator. Pod njegovim vodstvom so bili na Ptuju redni koncerti priznanih solistov in ansamblov. Leta 1930 sta med drugim nastopila zbora Glasbene matice Ljubljane in Maribora. Z ljubljanskim so pri šli kar trije takrat najvidnejši skladatelji, Lajovic, Adamič in Osterc, kar so Ptujčani razumeli kot svojevrstno priznanje svojemu delu. O tem, da bi se Pahor ob tej priliki s komerkoli dogovarjal o svojem nadaljnjem kompozicijskem šolanju, ni podatkov. Pač pa je povedno, da je mariborski zbor, ki ga je vodil Vasilij Mirk, na gostovanju na Ptuju izvedel Pahorjevo Vipavsko, ki je edini znani primer izvedbe njegovega dela v tem času in hkrati dokaz, da je bil kljub dotlej skromnemu opusu že upoštevan skladatelj. ${ }^{25}$

Maja 1930 je bil z dekretom premeščen v Maribor, kjer se je redno zaposlil na Državnem moškem učiteljišču. Poučeval je violino in petje ter vodil zbor. Violino in teoretične predmete je honorarno poučeval tudi na glasbeni šoli Glasbene matice. V

19 Zgodovinski arhiv Ptuj, Fond Glasbena šola Ptuj, št. 1, ovoj št. 6, Pahorjevo pismo z dne 11. 11. 1925.

20 Skladba je objavljena v reviji Zbori, 1. 7, št. 3 (1931): 22.

21 Darja Koter, »Karol Pahor na Ptuju«, Pahorjev zbornik, 33-48.

22 NUK, Glasbena zbirka, mapa Karol Pahor.

23 Glej: Karol Pahor, "Snežec«, Nova muzika 2/1928, priloga Mala nova muzika.

24 Koter, "Karol Pahor na Ptuju«, Pahorjev zbornik, 48.

25 Prav tam, 49-50. 
Večerniku in reviji Obzorja se je ves čas udejstvoval kot poročevalec glasbenih dogodkov ter veljal za temeljitega in poštenega kritika. Kmalu po tem, ko se je v novem okolju ustalil, je stopil v stik s Slavkom Ostercem, in sicer s pomočjo kolegice Minke Zacherl, ki je bila kot pianistka (diplomantka ljubljanskega konservatorija), učiteljica petja in zborovodkinja sodelavka mariborske Glasbene matice. Zacherlova je bila na ljubljanskem konservatoriju sošolka in tesna prijateljica Emila Adamiča. Kot hči Franca Zacherla, vsestranskega ljutomerskega glasbenika, ustanovitelja tamkajšnje glasbene šole (1922), ki je imel stike s priznanimi kulturniki in glasbeniki, kot so Slavko Osterc, Ciril Pregelj, Fran Ksaver Meško, dr. Karol Grossmann in drugi, je imela širok krog glasbenih prijateljev. Znana je bila kot odlična interpretka, spremljevalka na klavirju in zborovodkinja. Skladatelji so ji v presojo pogosto pošiljali svoja dela za mladinske ali odrasle zbore, kar je pomenilo, da je bila zelo cenjena. Med drugim je kot korepetitorka sodelovala tudi s Trboveljskim slavčkom. ${ }^{26}$ S Slavkom Ostercem se je poznala od malih nog, po letih je bil njen vrstnik in predvsem družinski prijatelj. O tem, kdaj je Pahorja priporočila Ostercu, da bi ga poučeval v kompoziciji, ni znanih virov, predvidevamo, da v začetku leta 1932, kajti maja tega leta se je Pahor Ostercu pisno zahvalil za njegovo pripravljenost in zapisal: «Zelo sem bil v skrbeh, da me boste odbili. Začel bi torej najraje takoj in popolnoma od začetka po Vašem načinu. /.../ Sicer pa imate opravka z marljivim učencem, ki bo delal vse z velikim interesom in začel čim prej že praktično uporabljati Vašo šolo. ${ }^{27}$ Pahorjeva odločitev, da za učitelja kompozicije izbere prav Osterca, pove marsikaj. Gotovo je sledil njegovemu renomeju kot avantgardnemu skladatelju in priljubljenemu profesorju teoretičnih predmetov na srednji stopnji konservatorija ter imel jasne cilje - postati skladatelj in to skladatelj sodobnega kova. Ni znano, da bi razmišljal o drugih možnostih. Z Osterčevo privolitvijo, da začneta študij na daljavo in se občasno srečata v Ljubljani, se je Pahorju odprl nov svet, končno je stopil na pot, ki ga je vodila k uresničitvi življenjskih želja. Tudi Osterc je njuno sodelovanje vzel zelo resno ter se redno in poglobljeno odzival na Pahorjeve naloge, vprašanja, dileme... ${ }^{28}$

Iz njune korespondence razberemo, da Pahor v prvih lekcijah s harmonijo ni imel večjih težav, pač pa s kontrapunktom, za katerega je celo izjavil, da ga »ta slog niti najmanje več ne zanima ${ }^{29}$ Osterc je svojega učenca uril v tradicionalni fugi in razumevanju klasičnega glasbena stavka, saj je bil prepričan, da šele to znanje omogoča ustvarjanje "resne disonančne kompozicije «. ${ }^{30}$ Priporočal mu je takrat aktualne glasbeno-teoretične priročnike, med njimi Schönbergovo Harmonielehre, o kateri je menil, "da se jo rabi do smrti in še po smrti «. ${ }^{31}$ Čeprav ni bil velik ljubitelj Schönbergovega sloga, se je zavedal pomena njegovih teoretičnih priročnikov in vloge v modernistični glasbi. Tako je Pahorju nalagal vaje v 12 tonskem sistemu, ki naj bi služile pri »modernem instrumentalnem komponiranju«, ter vaje iz "harmoničnih stavkov v tonalni kromatiki« in "harmoničnih stavkov v atonalni kromatiki«.32 Pahor je bil sicer vztrajen, a

\footnotetext{
26 Prim. Bojana Škrlj, Ljutomerska glasbenika Franc in Minka Zacherl, mag. delo (Ljubljana: Akademija za glasbo, 2017), 45-52.

27 Cvetko, Fragment glasbene moderne: iz pisem Slavku Ostercu, 255. Odlomek iz Pahorjevega pisma Ostercu z dne 2. 5. 1932.

28 Prav tam, 255-63, prim. tudi Rijavec, "Pahorjevo predkompozicijsko dopisno šolanje pri Slavku Ostercu«, 121-31.

29 Cvetko, Fragment glasbene moderne iz pisem Slavku Ostercu, 257.

30 Rijavec, »Pahorjevo predkompozicijsko dopisno šolanje pri Slavku Ostercu«, 126.

31 Prav tam, 125.

32 Prav tam, 127-130.
} 
do določene mere neučakan, ko pravi: »Pisal bi rad akorde z 12 poltoni naenkrat tako, da zrušim dvorano s prvo orkestrsko skladbo!«.33 Ob tej izjavi ga je Osterc opomnil na pomen linearne gradnje glasbenega stavka, ki mu je kot neoklasicist tudi pripadal. ${ }^{34} \mathrm{~Pa}-$ hor se je v času sodelovanja z Ostercem v mariborskem okolju počutil nekaj posebnega, kot nekdo, ki mu je dano, da hodi po najsodobnejših glasbenih poteh, pri čemer se je zavedal, da v takratnih krogih nima sebi enakih. Svojimi glasbenimi kolegi je večkrat prišel navzkriž jih celo označil za malomeščane. Prizadeval si je, da bi tudi tamkajšnja glasbena scena dobila sodobnejši nadih, zato je Osterca nagovarjal, naj pride v Maribor s svojo četrttonsko glasbo, »da shecamo malo naše purgarje! «. ${ }^{35}$ Vse to je bila posledica nekaterih negativnih odzivov na njegova dela. ${ }^{36}$

Skozi večletno dopisno kompozicijsko šolo, kjer se je Osterc izkazal kot nepopustljiv učitelj, Pahor pa kot izjemno vztrajen in deloven študent, so nastala nekatera tehtna dela, s katerimi se je Pahor postavil ob bok tistim slovenskim skladateljem, ki so se profilirali kot neoklasicisti in snovalci atonalne glasbe. Osterc se je o njegovih delih večkrat izrazil zelo pohvalno, opazile pa so ga tudi razne žirije in mu podelile pomembne nagrade. Čeprav ni šlo vse tako, kot si je Pahor zamislil in je doživel marsikatero bridko na račun svojega opusa, ni klonil in ne odstopil od modernističnih prijemov, kot so načela atematske gradnje in atonalnosti. V nekaterih delih je verno sledil učitelju, npr. v obeh godalnih kvartetih, in sicer z ostrim kromatičnim stavkom, medtem ko je na ravni forme ostal v tradicionalnih okvirih štiristavčne sonatne oblike. Osterc je prvi godalni kvartet, ki je nastal konec leta 1935 in doživel premiero v mariborski Unionski dvorani kmalu po nastanku, označil za eno najboljših slovenskih del te vrste po prvi svetovni vojni. ${ }^{37}$ Opredelil ga je kot skladbo $\mathrm{v}$ »čisto pravilnem kvartetnem polifonem modernem dvanajsttonskem slogu« ${ }^{38}$ Podobna zasnovani so Drugi godalni kvartet, Pihalni trio in Trije divertimenti za flavto, oboo in fagot, medtem ko je klavirske skladbe predvojnega časa, kot so Tri arabeske za klavir (1936), pisal v t. im. "zmernem modernizmu«. Prav klavirski opus kaže na Pahorjevo namero, izhajati iz kompozicijske logike svojega profesorja, vendar se izogniti pretiranemu konstruktivizmu in doseči didaktičen namen. Te poteze glasbenega stavka klavirskih skladb je Leon Stefanija označil kot "zadržano naprednost« ter kot odraz njegove značajske lastnosti, ki ga je pri ustvarjanju vodila k »uporabni glasbi«. ${ }^{39}$ Spet drugačno izhodišče razberemo pri zborovski skladbi Očenaš hlapca Jerneje (1938), ki je nastala kot odraz Pahorjevega spoštovanja do Ivana Cankarja, ki ga je od mladosti zelo cenil, gotovo pa mu je bila blizu tudi sporočilnost njegovih del, med katerimi še posebno izstopa lik hlapca Jerneja. ${ }^{40} \mathrm{~V}$ njem zaznamo vpliv socialnorealistične smeri v slovenski umetnosti, zlasti v literaturi, ki je zaznamovala tudi likovno in glasbeno umetnost. Delo je zasnovano kot pravoslavni liturgični zbor, s poudarjeno vlogo besedila in njegovo tesno simbiozo z glasbeno teksturo, v sožitju tradicije in sodobnosti, kar kaže z inovativnim vodenjem

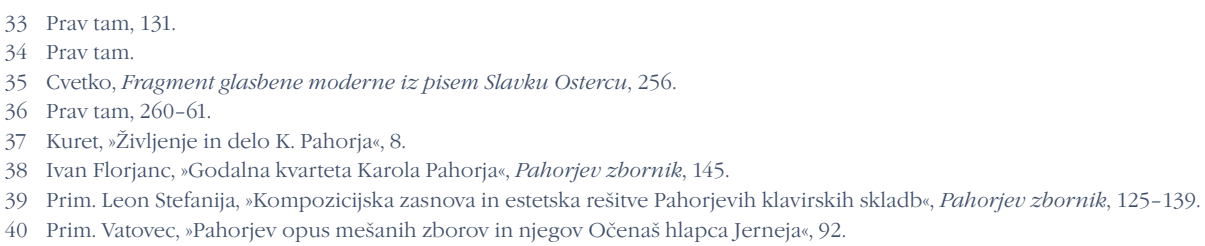


glasov in v drznih harmonskih zvezah. Z njim je dosegel največjo prepoznavnost in zdi se, da mu je »zlata sredina" med avantgardo in tradicijo tudi osebno najbolj ustrezala, saj se je na Osterčevo kritiko Očenaša, ki naj bi imel preveč tradicionalnih prvin, odzval z

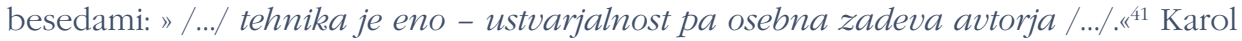
Pahor je bil v drugi polovici 30. let eden vidnejših modernistov, če izvzamemo Osterca, Šturma, Koporca... Sam je o tej dobi kasneje povedal: „Dosegel sem za takrat najekstremnejši vzpon pri obravnavanju glasbenega stavka-serialne dodekafonije in v tem slogu napisal tudi nekaj del.«2

\section{In od avantgarde nazaj $k$ tradiciji}

Začetek druge svetovne vojne je Pahorja prisilil v migracijo v Ljubljano, kjer se je honorarno zaposlil $v$ glasbeni šoli Glasbene matice in na srednji stopnji Glasbene akademije ter tam poučeval do jeseni 1943, ko je odšel v partizane. V Ljubljani je postal aktivist NOB in napisal prvo skladbo v revolucionarnem narodnem duhu z naslovom Partizanska (tudi $V b o j$ ) na besedilo Mateja Bora, ki so jo od leta 1942 izvajali na radiu Kričač. S tem delom se je spontano začelo njegovo obdobje ustvarjanja, ki je pomenilo skoraj popoln odmik od avantgardnih zamisli, ki jih je razvijal ob Ostercu in do začetka vojne. Nastajale so koračnice, revolucionarne pesmi, balade, samospevi in druge priložnostne skladbe za vsakdanjo rabo, pri katerih sta bili ob ustrezni vsebini in karakternosti v ospredju spevnost in oblikovna jasnost. Čeprav je v svojih delih sledil temeljnemu poslanstvu partizanske glasbe, je stremel k izvirnosti in slikovitim razpoloženjem. O tem pravi: »V tej vrsti glasbe pa nisem videl samo propagandnega sredstva, zahteval sem $v$ njih tudi umetniško raven. Moje koračnice in druge preproste pesmi naj bi bile odraz čustvovanja vsega ljudskega kolektiva, katerega član sem bil.«. ${ }^{43} \mathrm{O}$ svojem vojnem opusu je med drugim povedal: "Pri partizanski pesmi je oblikovanje na videz minimalno, $v$ resnici pa je treba ne samo spretnosti, temveč tudi domiselnosti in pravega občutka za vsebino /.../. Kar pa je še nad tem, je melodija sama, glavni nosilec vsebine, /.../, njen mogočni, neodvojljivi posrednik/.../.. ${ }^{44}$ Največ stika z njegovim predvojnim opusom imajo nekateri samospevi z razširjeno tonalnostjo, kot sta Ne bo me strlo (bes. Karel Destovnik Kajuh) in Pesem jetnika (bes. Jože Udovič), pa tudi ciklična skladba programskega značaja Slovenska suita za klavir, v kateri je razpet med tonalnostjo, enharmonijo in bitonalnostjo, medtem ko v razpoloženjih zaznamo onomatopoije, sicer značilne tudi za samospeve Marjana Kozine.45 Pahor slovi kot partizanski skladatelj, česar se ni nikoli sramoval in o tovrstnem opusu prepričljivo izjavil:

"V meni so zapele strune vse drugačno pesem, naenkrat so bila pozabljena vsa dolgoletna naporna natezanja s proučevanjem izumetničenih tonskih sistemov in

41 Povzeto po Vatovec, »Pahorjev opus mešanih zborov in njegov Očenaš hlapca Jerneja«, 95.

42 Povzeto Antoni, „Pahorjeva tržaška leta«, 23-24.

43 Rafael Ajlec, »Srečanja z umetniki partizani«, Ljudska pravica 21, št. 28 (1955): 6.

44 Franc Križnar, "Slovenska partizanska glasba in Karol Pahor", Pahorjev zbornik, 108

45 Koter, "Kozinovi samospevi in klavirja iz zapuščine«, Marjan Kozina / mednarodni simpozij o Marjanu Kozini (Novo mesto: Glasbena šola Marjana Kozine, 2002), 112-113. 
podobno. Ugotovil sem, da sem se v svojim mladih letih oddaljeval od človeka $v$ neizmerno težkem času. Vsa moja muzika, ustvarjena v tistem času, je dokaz, ki zgovorno utemeljujejo moj preobrat. " $^{46}$

Konec vojne zanj ni pomenil novega ustvarjalnega obdobja, prej bi rekli, da je čas narodnega boja in socialističnega duha v njem odmeval več let, podobno kot pri nekaterih drugih skladateljih, denimo pri Radovanu Gobcu in Radu Simonitiju. To je bila doba množične zborovske pesmi o mladini, delu, revoluciji, petletki.., ki je imela propagandni značaj. Najbolj vneti zagovorniki novih tokov in glasbenih direktiv so zborovodjem vsiljevali interpretacijo posameznih skladb, kot je na primer komentar prvega povojnega urednika Naših zborov Adolfa Groeblinga, ki je za izvedbo priljubljene Pahorjeve skladbe Komandant Stane strogo zapisal, naj bo njena interpretacija udarna, preprosta in naravna ter nikakor ne sentimentalna ali izumetničena. ${ }^{47}$ Sam Pahor pa je o svojem videnju vloge zborovske glasbe in njenih interpretov leta 1949 zapisal:

Danes se ustvarjajo tesni odnosi med delavskimi množicami in umetnostjo. Umetniki si prizadevajo izoblikovati nov slog, slog socialističnega realizma ali socialistične stvarnosti. Vaša naloga je, da jih v tem prizadevanju podpirate, da širite to glasbo in sploh dobro glasbo po vaseh in delavskih kolektivih in da dvigate umetniški nivo delounih množic, kajti danes je umetnost last delovanjih ljudi. ${ }^{48}$

Pahor je bil komunist še iz vojnih dni, zato je parole povojnih oblasti dobro obvladal, vprašanje pa je, ali jim je zares tudi verjel. Prenekateri slovenski umetniki in kulturniki so v vihri časov sledili uradni doktrini, pa čeprav jim ni bila zares blizu. V času informbiroja je Pahor celo doživel grenko izkušnjo, ko so ga kot profesorja glasbeno-teoretičnih predmetov na Akademiji za glasbo čez noč odstavili in poslali na daljši izredni dopust (1949-50). ${ }^{49}$ Ni povsem jasno, ali zaradi svaka, ki je bil politični oporečnik, ali zaradi česa drugega, s čimer naj bi ogrozil ustanovo, ki ji je pripadal..$^{50}$ Ko so se leta 1952 razmere nekako uredile, je ponovno sedel med profesorje in napredoval na delovno mesto profesorja kompozicije. Bil je dober pedagog in priljubljen profesor. ${ }^{51} \mathrm{~V}$ petdesetih letih se je angažiral kot predsednik Društva slovenskih skladateljev in si v tej vlogi med drugim prizadeval za ureditev avtorskih pravic, kar mu je tudi uspelo.

Družbeno-politična situacija je zaznamovala vse umetnike, posebno tiste, ki so bili deležni vojnih strahot in povojnega šikaniranja oblasti. Karol Pahor je bil med tistimi, katerih opus se je po vojni obrnil od avantgardnih smeri in se nagnil k folklornim prvinam in tradicionalnemu glasbenemu stavku. Bil je prepričan, da je njegovo poslanstvo

46 Povzeto po Antoni, "Partizanski samospev in Marjan Kozina«, Marjan Kozina - ob 10o letnici rojstva (Novo mesto: Glasbena šola, 2007), 141.

47 Adolf Groebming, »Pevske neokusnosti«, Naši zbori 3, št. 2 (1948): 3

48 Karol Pahor, »Referat o tretji republikanski reviji SKUD«, Naši zbori 4, št. 2 (1949): 8.

49 Prim. Rotar Pance, "Pedagoško delo K. Pahorja na Akademiji za glasbo«, 60.

50 O problematiki kulturnikov v času socrealizma in Pahorjevi povojni usodi glej strnjen prikaz v: Koter, Slovenska glasba $1918-1991$ (Ljubljana: Študentska založba, 2012), 246-58, 281-82.

51 Glej izjave v: Rotar Pance, »Pedagoško delo K. Pahorja na Akademiji za glasbo«, 65-70. 
v povratku h koreninam, kar naj bi bil edini porok narodove samoohranitve. ${ }^{52}$ Najbolj so ga zaznamovale istrska, prekmurska in belokranjska ljudska pesem; prvo je kot deček spoznal ob istrskih delavcih, drugo v Trstu od madžarskih vojakov, belokranjsko pa gotovo v partizanskih časih, povezanih z osvobojenimi ozemlji. Istrsko tematiko je večinoma vpletel v orkestralni opus, kot so Tri etude za klavir (1948), kasneje preoblikovane v orkestralno delo (Tri koncertne etude, 1955/56) ter v inačici še za klavir in orkester (Tri koncertne etude za klavir in orkester, do 1960). Kot ugotavlja Andrej Misson, se je v etudah odmaknil od svoje nekdanje estetike in se naslonil na bolj tradicionalno harmonijo, razložene akorde, paralelne terce in sekste, lestvične nize ter pisal oktavne nize z dodano kvinto ali kvarto. Vsa orkestralna dela so tonalna in potrjujejo skladateljevo violinsko znanje. Njegov slog se giblje znotraj tradicionalnih okvirjev, s katerim je morda skušal doseči manj zahtevnega poslušalca, kot je bilo v povojnih letih tudi pričakovano. ${ }^{53}$ Najbolj cenjena med instrumentalnimi deli je suita za klavir Istrijanka, katere zametki segajo v partizanski čas, ki ga je Pahor preživel na Mirni gori nad Belo krajino. Kot klavirsko delo je bilo dokončano v letih 1950-51 in posvečeno istrskemu skladatelju Matetiću-Ronjgovu, ki ga je zelo cenil. Čez pet let je skladbo predelal za zasedbo pihal (1956) in podnaslovil kot »15 plesnih miniatur v duhu istrske narodne melodike za simfonična pihala«. V njem je ohranil prvinskost istrske lestvice, odnos celih tonov in poltonov, ki se v modusu značilno izmenjujejo, ozek ambitus, sekundno gibanje ter vodenje glasov v malih tercah. ${ }^{54}$ Glasbene miniature so odlikujejo po kratkih temah, izvirnih kontrastih v tempu in značajih, kot celota pa po prepričljivi epsko naravnani pripovedi.

Od začetka petdesetih let se je Pahor vse bolj posvečal zborovski glasbi za otroke in mladino, skupno pa je zanje skladal več kot 50 let, pri čemer je izbiral najtehtnejša besedila slovenskih pesnikov. Za tiste predvojne je značilno avantgardno glasbeno tkivo, skladno z drugimi glasbenimi oblikami svojega časa (prim. Poľ̌ja suita, 1938), po vojni pa se je tudi v tem opusu umiril in stopil v bolj tradicionalno smer (Najdihojca, 1950, Petdeset ugank, 1953, Belokranjske otroške pesmi, obj. 1. 1953/54, Tancaj, tancaj črni kos, 1952-57). Skladbam je praviloma vtisnil didaktično noto in ustvarjal v prepričanju, da je za mlade dobro le najboljše. Poudarjal je, da ima tedanja narodno-zabavna glasba na otroke kvarni vpliv ter da kazi okus in sposobnost vrednotenja resnih glasbenih del. Tudi v tem opusu najdemo ljudsko melodiko Istre in Bele krajine, ob tem pa tonsko slikanje prizorov iz otroškega življenja. Ustvarjal je tonalno, vendar v prepričljivem njemu lastnem glasbenem jeziku, z občutkom za glasovni razpon določenih starostnih skupin in skladnost glasbenih prvin s povednostjo besedila. Posebej izstopa zbirka Pedenjped (bes. Niko Grafenauer), izšla 1974, sestavljena kot niz malih umetnin, od katerih ima vsaka svoj tehnični vozel in sodi med zahtevnejša dela te vrste. V njih najdemo številne modulacije, večje skoke, pogosto menjavanje taktovskih načinov in raznolike drobne izrazne odtenke. Izjemno tehtne so tudi klavirske spremljave v obliki variacij, vprašanj in odgovorov, ki tehtno in izvirno dopolnjujejo pevski part. ${ }^{55}$

52 Prim. Vatovec, „Pahorjev opus mešanih zborov in njegov Očenaš hlapca Jerneja«, 85.

53 Andrej Misson, »Pahorjeva orkestralna dela", Pahorjev zbornik, 155-169.

54 Pavel Mihelčič, »Pahorjev odnos do folklore«, Pahorjev zbornik, 151-154.

55 Prim tudi Sonja Kralj Bervar, »Pahorjevi otroški in mladinski zbori«, Pahorjev zbornik, 75-83. 


\section{Za zaključek}

Karol Pahor se je kot skladatelj proslavil na več ravneh: prepoznan je kot eden najznačilnejših učencev Osterčeve šole, iz katere izstopata oba godalna kvarteta in samospev Večer je, večer. Antološka je njegova sklada Očenaš hlapca Jerneja in priredba primorske ljudske $\mathrm{Pa}$ se sliš, s katerima je trajno zaznamoval slovensko zborovsko glasbo. Večne so njegove partizanske pesmi Na juriš, Hej, brigade in ne nazadnje Komandant Stane, otroški zbori prepevajo pesmice njegovih številnih zbirk in ne nazadnje, legendarna je tudi njegova Istrijanka, ki v slovenski literaturi velja za eno pomembnejših del na ljudsko temo. Čeprav mu v mladosti zaradi težkih osebnih razmer ni bilo dano, da bi se izobrazil za komponista in se je moral zadovoljiti s poklicem učitelja violine, je z neumorno voljo in s trudom svoje želje kasneje dosegel. Po zelo tradicionalnih skladateljskih začetkih, kot jih je zmogel s srednješolskim glasbeno-teoretičnim znanjem in z lastnim delom, je imel pri svojih 35. letih dovolj samozavesti, da se je obrnil na avantgardnega skladatelja in učitelja sodobnih kompozicijskih tokov Slavka Osterca. Naj spomnimo, da Osterc kot modernist v ljubljanskih krogih ni doživljal vsestranskega priznanja, največ potrditev je požel na tujem, doma pa od svojih učencev. Pahorjeva izbira se zdi precej drzna tudi zato, ker je živel v Mariboru, kjer modernistična glasba ni bila del vsakdanjika, prej bi rekli, da si je šele utirala pot na tamkajšnje odre. Dopisna šola je Pahorja nedvomno profilirala in zaznamovala za vse življenje, pa čeprav svojemu učitelju ni dosledno sledil. Od leta 1932 do začetka druge svetovne vojne je sicer pisal v takrat avantgardnih tehnikah, vendar se je pri določenih glasbenih oblikah, predvsem zborih in klavirskih miniaturah, nekoliko brzdal in ustvarjal v slogu "zmernih modernistov«, najbrž zato, ker si je prizadeval, da bi njegova glasba prišla med ljudi. Iz prvih pisem Ostercu razberemo, da mu je bila atonalna glasba prvi cilj in da je bila zanj to edina pot, s katero lahko obeleži duh časa, vendar je svojo slogovno usmeritev kmalu omilil. Čeprav o družbeno-političnih situacijah svoje dobe ni pisno razpravljal, se zdi, da je bil zelo tankočuten in dovzeten za njihove vplive. To se je potrdilo z začetkom druge svetovne vojne, ko je hipoma prevzel slog partizanske glasbe in z njim iskreno zaživel. Ob vrsti koračnic, revolucionarnih in drugih priložnostnih pesmih se je sicer tu in tam »spomnil« svojega širokega spektra glasbeno-teoretičnih znanj in ustvaril kaj v sodobnejših smereh, vendar to ni bila več njegova pot. Po vojni je izhajal iz kolektivističnega duha in pisal v mejah estetske in umetniške kategorije socrealizma, a ne povsem dosledno. Svoje zanimanje je usmeril v ljudsko glasbo, kar bi lahko pomenilo, da se je s tem spretno izmuznil poudarjanju ideoloških vsebin. Posvetil se je orkestralnim skladbam z istrsko in belokranjsko tematiko in ustvaril tehtna dela, v katerih je spretno krmaril med tradicionalnim in smelejšim glasbenim stavkom. Največ pozornosti pa je usmeril k otroškim in mladinskim zborom, ki jim je želel zapustiti čim več pristne glasbe, takšne, ki nagovarja k iskrenosti. Tak obrat je bil posledica številnih razočaranj nad kolegi v stroki, kar mu je rahljalo samozavest in ga končno odtegnilo od družbenih okolij in pahnilo v osamo. Svoj opus je sklenil z zbirko otroških pesmic Pedenjped Nika Grafenauerja, s katero pa se je vendarle poslovil v iskrivem duhu. 


\section{Bibliografija}

Ajlec, Rafael. »Srečanja z umetniki partizani«. Ljudska pravica 21, št. 28 (1955): 6.

Cvetko, Dragotin. Fragment glasbene moderne: iz pisem Slavku Ostercu. Ljubljana: Slovenska akademija znanosti in umetnosti, 1988.

Groebming, Adolf. »Pevske neokusnosti«. Naši zbori 3, št. 2 (1948): 3.

Koter, Darja. »Kozinovi samospevi in klavirja iz zapuščine«, Marjan Kozina / mednarodni simpozij o Marjanu Kozini. Novo mesto: Glasbena šola Marjana Kozine, 2002: 107-122.

Koter, Darja. Slovenska glasba 1918-1991. Ljubljana: Študentska založba, 2012.

Pahor, Karol. »Referat o tretji republikanski reviji SKUD«. Naši zbori 4, št. 2 (1949): 5-8. Rijavec, Andrej. »Pahorjevo predkompozicijsko dopisno šolanje pri Slavku Ostercu«. Muzikološki zbornik XXV (1989): 121-131.

Škrlj, Bojana. Ljutomerska glasbenika Franc in Minka Zacherl, mag. delo. Ljubljana: Akademija za glasbo, 2017.

Škulj, Edo, ur.. Pahorjev zbornik. Ljubljana: Akademija za glasbo, 2005.

Waltritsch, Marko. Šola Glasbene matice v Gorici: ob 25. Letnici. Gorica: Šola Glasbene matice v Gorici, 1987.

Zupančič, Maruša. »V iskanju lastne identitete: češki violinisti kot glavni tvorci violinizma na Slovenskem«. De musica disserenda, IV/2 (2008): 105-118.

Žgur, Fran. »Karol Pahor«, Zbori III, št. 3-4 (1927): 14.

Arhivski viri

Zgodovinski arhiv Ptuj, Fond Glasbena šola Ptuj. Pisma Karola Pahorja.

NUK, Glasbena zbirka, mapa Karol Pahor.

NUK, Glasbena zbirka, mapa Vasilij Mirk.

Arhiv Akademije za glasbo, personalna mapa Karol Pahor.

\section{SUMMARY}

Composer Karol Pahor (1896-1974) stood out on several levels and is recognized as one of the most distinguished students of Slavko Osterc, a Slovenian modernist from the time between the two world wars. Under his influence, Pahor absorbed a neoclassical and atonal style, where two string quartets are standing out and solo Večerje, večer (It is evening, evening) (lyrics by Alojz Gradnik). The anthology of his compositions includes Očenaš hlapca Jerneja (The Lord's Prayer of servant Jernej) (Lyrics by Ivan Cankar), and the adaptation of the coastal folk song Pa se sliš' (You can hear), which permanently marked Slovenian choral music. His partisan songs Na juriš (In a rush), Hej, brigade (Hey brigades), and, of course, Komandant Stane (Commandant Stane) are eternal, children's choirs sing many of the songs in his collections. Last but not least, his instrumental composition Istrijanka, which is one of the most important works on the folk theme in Slovenian literature, is also legendary. He enrolled in the study of composition at the University of Music and Performing Arts Vienna, but because of a difficult personal situation, he was only there for a short time. After graduating from the Il Liceo Musicale di Bologna (Musical High school in Bologna), he had to satisfy himself with the profession of a violin teacher, but later on, he reached his goals. After very traditional compositional beginnings, he turned in 1932 to the avant-garde composer and teacher of contemporary compositional style, Slavko Osterc, and with him, he began a long-standing correspondence school of composition. Osterc, as a modernist in Ljubljana's circles, did not experience all-round recognition, most of his approval came from abroad and from his students, today, however, he is considered the greatest Slovenian modernist of his time. Pahor was undoubtedly profiled and marked for all his life by 
him, even though he did not consistently follow in his teacher's footsteps. In the second half of the 30s, he wrote in the then-avant-garde techniques, but in certain musical forms, mainly choirs and piano miniatures, he restrained himself and worked in the style of the "moderate modernists", probably because he strived for his music to get on well among the people. He recognized atonal music as the only one with which he could mark the spirit of the time, but he soon eased his stylistic orientation. He was very sensitive and susceptible to socio-political influences. This was confirmed by the beginning of the Second World War when he promptly took over the style of partisan music and sincerely came to life with it. In addition to marches, revolutionary poetry, and other occasional poems he composed, he sometimes created some work in the avant-garde direction, though this was no longer his style. After the war, he emerged from the collectivist spirit and wrote within the limits of social realism, though not always consistently. He focused his interest on folk music, possibly as a manoeuvre to avoid emphasising ideological content. He devoted himself to orchestral compositions with Istria and Bela krajina themes and created valuable works in which he skilfully navigated between traditional and avant-garde music. He dedicated most of his attention to children's and youth choirs, whom he wanted to leave as much genuine music as possible, the kind of music that encourages an honest character. Such a turn was the result of many disappointments over colleagues in the profession, which caused a loosening of self-confidence and finally kept him from social environments and shoved him into isolation. He concluded his opus with a collection of children's songs, Pedenjped by Niko Grafenauer, with which he bid farewell in witty spirit. 